\title{
CAMLG wt Allele
}

National Cancer Institute

\section{Source}

National Cancer Institute. CAMLG wt Allele. NCI Thesaurus. Code C51106.

Human CAMLG wild-type allele is located within $5 q 23$ and is approximately $14 \mathrm{~kb}$ in length. This allele, which encodes calcium signal-modulating cyclophilin ligand protein, plays a role in the calcium signal transduction pathway. 